longest surviving of them all. Neither he nor any of his brothers were married; one sister was, but she left no brothers were marrier, in I793. Between 1803 and 1808 he was a pupil at the High School, Edinburgh, after leaving which he entered the University of that city as a medical student, attending the lectures of Drs. Monro, Hope, Gregory, Duncan, and others. He took his doctor's degree in I8I4, for five years after which he devoted his time to travelling on the Continent, visiting Paris, Rome, Florence, as well as Germany, Bohemia, Hungary, and Austria. In 1822 he settled in Edinburgh, and from then till 1828 contributed several zoological papers to different Scot scientific societies and journals, including one to the Wernerian Natural History Society, in 1827 , on the circulation of fluids through the structure of sponges, in which attention was first drawn to the function of the ossicula and pores of those animals, and which led Mr. Fleming to give the generic name Grantia to one member of the family.

In June 1827 , whilst still in Edinburgh, Dr. Grant was elected Professor of Zoology and Comparative Anatomy in the new University of London, then being formed; his first lecture was not however delivered until October 1828 . For the first few years after he settled in London he communicated several papers on zoological subjects to the Scientific Committee of the Zoological Society, some of which, on points in the anatomy of Sepiola, Loligopsis, and Beroë, read in 1833 , are to be found in the first volume of their Transactions. From that time Dr. Grant published no papers of importance.

In I 836 Dr. Grant was elected a Fellow of the Royal Society, and in 1837 he was appointed to the triennial Fullerian Professorship of Physiology at the Royal Institution in Albemarle Street.

At his classes, during one session, it is said that Dr. Grant had only two attendants, these being Mr. Hallam, the illustrious historian, and a young boy; it was always a matter of surprise to the other students of the college how he managed to adapt his lectures to the mental capacity of this trying audience.

During the forty-six years that he held his professorship, he never missed a single lecture. It was his determination, if he had lived, to resign his appointment during the present year.

In disposition Dr. Grant was very retiring and seclusive, and a great reader. He travelled much and was an excellent linguist ; so fond of languages was he, that only two years ago he attended lectures on Anglo-Saxon in University College. By his will Dr. Grant leaves his extensive library and all his private collection to University College, together with a sum of money to be employed in maintaining and extending the zoological and zootomical department of the library of the college.

\section{CONFERENCE FOR MARITIME METEOROLOGY}

A GENERAL wish having of late been expressed that the measures for the prosecution of Maritime Meteorology, proposed at the International Conference at Brussels in 1853 , should be reconsidered, now that the experience of more than twenty years of the operation of these measures has enabled meteorologists to form opinions as to their utility, a conference is now being held at the Meteorological Office, II6, Victoria-street, consisting of the following gentlemen :-Austria-R. Müller, K. K. Hydrographic Office, Pola. *BelgiumVan Rysselberghe, Navigation School, Ostend. BengalH. F. Blanford, Meteorological Office, Calcutta. ChinaJ. D. Campbell, Secretary Commissioners of Maritime Customs. Denmark-Capt. N. Hoffmeyer, Meteorological Institute, Copenhagen. France-C. Sainte-Claire Deville, Inspector of Meteorological Stations; A. Dela- marche, Ministry of Marine, Paris. Germany-W. H. von Freeden, Deutsche Seewarte, Hamburg ; G. Neumayer, Hydrographer, Berlin ; Capt. Stempel, Imperial Navy; H. A. Meyer, Commissioner for Investigating German Seas, Kiel. Great Britain---(Board of Trade), Capt. Toynbee; R. H. Scott, Director Meteorological Office, Hon. Sec. ; *(Admiralty), Rear-Admiral Nolloth ; R. J. Mann, M.D., President Meteorological Society. Holland -Buys Ballot, Royal Meteorological Institute, Utrecht, President; Lieut. J. E. Cornelissen, R.N. Italy - Capt. N. Canevaro, R.N. Norway-H. Mohn, Meteorological Institute, Christiana. Portugal-J. C. de Brito Capello, Observatory, Lisbon. Russia-Capt. M. Rikatcheff, I.R.N., Central Physical Observatory, St. Petersburg; *A. Movitz, Observatory, Tiflis. Spain-C. Pujazon, Marine Observatory, San Fernando; Captain Montijo, S.N. *Turkey-Admiral Hobart Pacha. The basis of discussion will be the Report of the Brussels Conference above referred to, with some other heads relating to instructions, instruments, \&c. The Conference will be divided into two sub-committees:- I. Instruments ; 2 . Observations. A Report of the proceedings will be published by the Meteorological Committee. A programme has already appeared in NATURE, vol. x. p. 152 .

\section{DEEP-SEA SOUNDINGS IN THE PACIFIC OCEAN}

$W^{\mathrm{E}}$ take the following extracts on this subject from a report made to the United States Secretary of the Navy by Commander George E. Belknap, dated United States Steamer Tuscarora, Hakodadi, Japan, June 26 :-

"I left Yokohama on the 8th inst., and at dawn the next morning began the work of sounding homeward on a great circle passing through the island of Tawaga, of the Aleutian group, and towards Puget's Sound. When about 100 miles east by south from Kinghasan or Sendai Bay, on the east coast of Japan, the lead sank to a depth of 3,427 fathoms, showing a descent of 1,594 fathoms in a run of 30 miles. The result seems extraordinary at so short a distance from the land, but the next coast revealed a depth still more astonishing, the sinker carrying the wire down 4,643 fathoms without reaching the bottom.

"On this occasion, when some 500 fathoms of wire had run out, the sinker was suddenly swept under the ship's bottom by the strong undercurrent, and all efforts to get the wire clear and keep it from tending underneath were unavailing, the difficulty being increased by a fresh breeze and a moderately heavy sea. Finally, when 4,643 fathoms of wire had run out, and only 150 fathoms of wire were left on the reel, it broke close to the surface, and about five miles were lost.

"The strain on the reel was very great, and notwithstanding a weight of $\mathrm{r} 30 \mathrm{lb}$. on the pulley. line, it took three men to check and hold the drum, and the wonder was that the wire had not parted sooner. This great strain must have been due to the action of the strong undercurrent upon the sinker, sweeping it with great force from the ship, as since that cast we have sounded repeatedly in depths of more than 4,000 fathoms, and had no trouble in reaching the bottom.

"The position of the cast, as shown by observation was about 45 miles distant from the previous one, the strong current having carried the ship beyond the position where it was intended to sound. . . . .

"I determined to run back inshore and skirt the stream, beginning a new great circle off Point Komoto, in latitude $40^{\circ}$ north. I also concluded to increase the weight of the sinker some $20 \mathrm{lb}$. ....

"It will be seen, by an inspection of the track chart of sounding, that the moment the second line diverges from the coast of Niphon and enters the edge of the Japan

* Not present at the meeting on Aug. $3 \mathrm{r}$. 
stream, but yet runs parallel to the island of Yesso, the water begins to deepen rapidly, and at the cast No, 24, or the third cast from the initial point of curve, a depth of 3,493 fathoms is found. Forty and eighty miles further on depths of 3,587 fathoms and 3,307 fathoms are reached; then the ocean bed or trough of the stream drops nearly a statute mile in the run to the next position, where the sinker is not detached until it has descended to the extraordinary depth of 4,340 fathoms.

"A good specimen of bottom soil was brought up from that great depth, and the Miller's Casella thermometer, No. 18,136 , came up a perfect wreck. . . . .

"The next six casts were made in over 4,000 fathoms water, the last two revealing depths of 4,4 I I fathoms and 4,655 tathoms respectively, and on both occasions the wire was lost. ....

"Sometimes the wire comes in much easier than at others, and cast No. 3I, made in 4, I 20 fathoms, occupied only $\mathrm{rh} .47 \mathrm{~m} .42 \mathrm{~s}$.

"The difference must be due to the varying action of the undercurrents upon the rod, specimen cup, and small lead, increasing or diminishing the resistance in hauling in, according to the extent of curve from the perpendicular. ....

"The conditions under which all these deep casts werc made were eminently favourable. Believing that such deep water would be impracticable for cable purposes, I resolved to run inshore and sound back along the coast of the Kurile Islands to the position of cast No. 22, then to return and skirt those islands and the coast of $\mathrm{K}$ Kamschatka as far as Cape Chipounsky, then passing over to the Alutian group. ....

"If the time on the great circle route for the proposed cable has failed, at least for the present, the results of these soundings will be of interest and value to hydrographic science, as establishing the fact of depths in the sea hardly to be expected, in view of the numerous soundings made by her Majesty's steamship Challenger and this ship, over wide expanses of the Atlantic, Pacific, and Indian Oceans, and confirming the existence of a very deep trough under the Japan stream, similar to that cut by the Gulf Stream on our own coast. . . . .

"As we passed by Sturup, of the Kurile group, dense volumes of smoke were seen rising out of a crater on the east end of the island."

\section{PROCEEDINGS OF THE FRENCH ASSOCIATION}

$\mathrm{O}^{\mathrm{N}}$

$\mathrm{N}$ Sunday the 23rd there was an excursion to Boulogne, to visit the steel-pen factory established by the Blanzy Company, and the Laboratory of Zoology, which Prof. Giard of Lille has organised by the seaside. On Monday many members paid a visit to Turcoing and Roubaix, two large manufacturing places in the vicinity of Lille, where the visitors were received with much courtesy; every workshop was eagerly thrown open for inspection.

At a general session held in the evening, M. Ménier, the large chocolate manufacturer who has realised an immense fortune in his trade, delivered a very appropriate lecture on the creation of wealth by science. No one has had so much practical experience on that subject in the society. M. Alglave, formerly a professor in the Academy of Douai, gave an impressive address on coalmining in Northern France. It was the first time that $M$. Alglave, who is very popular in Northern France, was allowed to deliver an address since he got into difficulties with the Government. His address created quite a sensation in the city.

On Tuesday there was a general excursion to Anzin coal-mines. A splendid luncheon was given to the visitors by the Anzin Company, in a large storehouse tastefully ormamented for the occasion with national flags and a trophy of all implements used by miners in their underground industry. M. Marsilly, the general director, proposed "The Visitors," in the name of the Council of Administration. M. Wurtz, in return, proposed "The Council and the illustrious President," whom he did not name, but who is no less a person than $M$. Thiers, at the mention of whose name enthusiastic cheers broke forth, interrupting $M$. Wurtz for more than five minutes. M. de Marsilly delivered a very long and able address, summarising all that the mining industry owed to science, and giving a few curious figures relating to his Company. It is 137 years old, and was the first French firm to import steam-engines from England. The number of hands is 15,000, and persons depending upon them 60,000. They are now constructing steam-engines, of 500 horse-power, for underground work. The society visited the Haveley pit, one of the forty belonging to the Company, whose concession covers about 100,000 acres, and is said to be worth more than $8,000,000$ sterling. On the same evening M. Gaston Tissander delivered an address on aërostation specially considered as to its meteorological uses. The lecture was illustrated by diagrams showing forms of clouds, optical phenomena connected with aërostation, \&c.

On Wednesday all the Sections were busy discussing the several communications, and held two sessions. M. Bergeron gave a most interesting address in the Engineering Department, on the boring of the tunnel between France and England. He said, upon authority, that the French Government had sent to Lord Derby a note asking him if he objected to the granting of the exclusive right for a number of years to a private Company. If the English Government does not raise any objection, the bill will be laid before the Versailles Assembly at the end of the present parliamentary holidays. Special provisions will be made for inundating the tunnel in case of war breaking out between the two countries. The holders of the concession can renounce their rights after spending $80,000 l$, in boring a gallery of exploration at least 1,100 ft. under the sea from low-water mark. The works are to begin on the French side as soon as the concession will have been granted. MM. Léon Say, Rothschild, André, \&c. are amongst the petitioners.

There was a very sharp discussion in the Anthropological Section on some theological points which had been raised.

In the evening Col. Laussedat delivered a lecture on optical military telegraphy. Almost all the officers of the garrison were present at the lecture, which was practically illustrated by various experiments.

In the morning of Thursday the business of the Sections was transacted as on the previous day, and at one o'clock a general meeting was held in the Hotel de Ville under the presidency of M. Wurtz. Some modifications of the by-laws and regulations of the society were unanimously adopted, and the committee was instructed to ask from the Government a decree declaring the society of public utility. This is a step necessary, according to the French laws, to give societies the right of holding properties, accepting legacies, and obtaining parliamentary grants.

M. Wurtz had directed a message to the British Association asking them to send a delegation to take part in the Lille meeting. This could not be accomplished, owing to the distance, but it ended in an exchange of telegraphic courtesies between the two societies.

The British Association being our model, it is necessary for us to study its workings, in order to adapt them as far as we can to our French circumstances and scientific pecularities. Consequently, the committee was instructed not to name the opening day for the 1875 meeting before ascertaining whether it shall not coincide with the opening of the next session of the British Association.

Two cities were in competition for the 1875 meeting Clermont Ferrand, where the Puy de Dome Observatory 